\title{
Serum FGF-23 levels in predialysis chronic kidney disease are not associated with $25-\mathrm{OH}$ D vitamin levels
}

\section{Prediyaliz kronik böbrek hastalarında serum FGF-23 seviyeleri, 25-OH D vitamin düzeyleri ile ilişkili değildir}

\author{
Gulsah SASAK ${ }^{1} \odot$, Banu ISBILEN BASOK ${ }^{2} \odot$
}

\begin{abstract}
Aim: Vitamin D has been found to have effects on the neurological, immunological and endocrine systems in addition to its effects on bone mineral metabolism. Similar to the population in general , in patients with chronic kidney disease (CKD), vitamin D deficiency has been shown to be associated with progression of renal disease, increased cardiovascular mortality and morbidity. In this study, we aimed to determine the factors affecting the vitamin D level in our CKD patients.
\end{abstract}

Method: One hundred and twenty patients with CKD but not on dialysis who were admitted to our nephrology clinic were included in the study.

Results: Sixty-eight patients (56.7\%) had vitamin D deficiency, 47 (39.2\%) had vitamin D insufficiency. Sixty-eight patients had vitamin D levels of $<15 \mathrm{pg} / \mathrm{ml}$ and $>56 \mathrm{pg} / \mathrm{ml}$ in 56 patients. Vitamin D levels in patients with, and without DM were $12.9 \pm 6.6 \mathrm{pg} /$ $\mathrm{ml}$ and $16 \pm 8.1 \mathrm{pg} / \mathrm{ml}$, respectively with a statistically significant intergroup difference $(p<0.05)$. In univariate correlation analysis, vitamin $D$ was negatively correlated with phosphorus ( $r s=-0.30$, $p<0.001)$, PTH $(r s=-0.34, p<0.001)$, proteinuria $(r s=-0.22)$ and $D M(r s=-0.19, p<0.05)$, while positively correlated with hemoglobin $(r s=0.27, p<0.001)$. However we did not find any correlation between 25-OH-D and FGF 23 and ( $r s=-0.122, p=0.183$ ), eGFR $(p=0.183, r s=0.135)$. In multivariate linear regression analysis, only PTH (beta $=-0.24, p<0.01$ ) and glomerular filtration rate (beta $=-0.215, p<0.05$ ) were found to have a negative effect on vitamin $D$.

Conclusion: In recent years, in addition to classical mineral metabolism of vitamin $D$, its pleotropic role and clinical consequences in predialysis CKD patients have been better understood. For this reason it is of great importance to know the factors affecting the vitamin D levels in this patient group and to consider them in the treatment of the patients.

Keywords: Chronic renal failure, vitamin D, mineral metabolism öz

Amaç: D vitamini, kemik mineral metabolizması üzerine etkileri dışında, nörolojik, immun sistem ve endokrin sistem üzerine etkileri olduğu saptanmış, bu da D vitamini üzerine olan ilgiyi artırmıştır. Kronik böbrek hastalığı (KBH) olan hastalarda genel populasyona benzer şekilde D vitamin eksikliğinin böbrek hastaığının ilerlemesi, kardiovasküler mortalite ve morbiditede artış ile ilişkili olduğu gösterilmiştir. Biz de bu çalışmamızda, takip ettiğimiz $K B H^{\prime} l i$ hastalarda $D$ vitamin düzeyine etki eden faktörleri saptamayı amaçladık.

Yöntem: Hastanemiz Nefroloji Kliniğine başvuran, KBH olan ve diyalize girmeyen 120 hasta çalışmaya alındı.

Bulgular: Hastaların 68'inde $(\% 56,7)$ D vitamin eksikliği, 47'sinde $(\% 39,2)$ D vitamin yetmezliği vardı. Altmış sekiz hastanın D vitamin düzeyi < $15 \mathrm{pg} / \mathrm{ml}, 56$ hastanın ise $>15 \mathrm{pg} / \mathrm{ml}$ üstünde idi. Diabetes mellitusu (DM) olanlar ve olmayanlar karşılaştırıldığında, DM olanlarda $D$ vitamin düzeyi; $12,9 \pm 6,6 \mathrm{pg} / \mathrm{ml}$ iken, DM olmayanlarda bu düzey 16,0 $\pm 8,1$ idi. Aradaki fark istatistiksel olarak anlamlıydı $(p<0,05)$. Korelasyon analizi sonucunda $D$ vitamini, fosfor $(r s=-0,30, p<0,001)$, PTH $(r s=-0,34, p<0,001)$, proteinüri $(r s=-0,22$, $p<0,05), D M$ varlığı $(r s=-0,19, p<0,05)$ ile negatif korele iken, hemoglobin $(r s=0,27, p<0,001)$ ile pozitif korele idi. Fakat 25-OH-D ile FGF 23 ( $r s=-0,122, p=0,183)$ ve eGFR $(r s=0,135, p=0,41)$ arasında ise herhangi bir ilişki saptanamadı. Çok değişkenli doğrusal regresyon analizinde ise yalnızca PTH (Beta $=-0,24, p<0,01)$, eGFR (Beta=$0,215, p<0,05) D$ vitamini üzerine negatif etkili bulundu.

Sonuç: Son yıllarda D vitaminin klasik mineral metabolizması dışında pleotropik rolü ve özellikle de prediyaliz $K \mathrm{KH}^{\prime}$ lı hastalarda bunun klinik sonuçları daha iyi anlaşılmıştır. Bu nedenle de bu hasta grubunda D vitamini düzeyine etki eden faktörleri bilmek ve hastanın tedavisinde bunları göz önüne almak büyük önem taşımaktadır.

Anahtar kelimeler: Kronik böbrek yetmezliği, D vitamini, mineral metabolizması

Received: 17.04 .2018

Accepted: 24.07.2018

${ }^{1}$ Istanbul Medeniyet University, Goztepe Training and Research Hospital, Department of Nephrology, Istanbul, Turkey

${ }^{2}$ University of Health Sciences Tepecik Training and Research Hospital, Department of Biochemistry, Izmir, Turkey

Yazışma adresi: Gulsah Sasak, Istanbul Medeniyet University, Goztepe Training and Research Hospital, Department of Nephrology, Istanbul, Turkey

e-mail: gulsahsasak@gmail.com

Yazarların ORCiD bilgileri:

G.S. 0000-0003-4395-4368, B.I.B. 0000-0002-1483-997X 


\section{Giriş}

D vitaminin bilinen kemik mineral metabolizması üzerine etkileri dışında, nörolojik, immun sistem ve endokrin sistem üzerine etkileri olduğu saptanmışs, bu da D vitamini üzerine olan ilgiyi artırmıştır. Dünya genelinde 1 milyar kişinin D vitamini eksikliği olduğu tahmin edilmektedir ${ }^{1}$. Kronik böbrek hastalıklı (KBH) hastalarda D vitamini eksikliği, yapılan çalışmalarda \%40-\%100 arasında değişmektedir ${ }^{3-5}$. Prevelansdaki büyük farkın nedeni $D$ vitamini eksikliğini tanımlamada farklı eşik değerlerinin kullanması olabilir. En son KDiGO kılavuzunda $25(\mathrm{OH}) \mathrm{D}$ düzeyinin $<15$ $\mathrm{pg} / \mathrm{ml}$ olması $\mathrm{D}$ vitamini eksikliği, $15-30 \mathrm{pg} / \mathrm{ml}$ arasındaki düzeyler ise $\mathrm{D}$ vitamini yetmezliği olarak tanımlanmıştır ${ }^{6}$ KBH'lığı olan hastalarda $\mathrm{D}$ vitamini eksikliğinin böbrek hastalığının ilerlemesi, kardiovasküler mortalite ve morbiditede artış ile ilişkili olduğu gösterilmiştir ${ }^{4,7}$. D vitamini eksikliği artmış yaş, diyabet (DM) ve hipertansiyon (HT) gibi eşlik eden hastalıkların varlığı, obesite gibi durumlarla ilişkili bulunmuştur ${ }^{6,8}$. Son zamanlarda keşfedilen Fibroblast growth faktör-23 (FGF-23) kemikte üretilen fosfatürik etkisi olan ve 1-alfa hidroksilaz enzimini inhibe eden bir proteindir. Renal fonksiyonlarda azalmaya paralel bir şekilde düzeyi arttığı gösterilmiştir ${ }^{9,10}$. $\mathrm{KBH}^{\prime} \mathrm{l}$ ' hastalarda kemik-mineral metabolizmasında rolü olduğu ve 1 alfa hidroksilaz enzimini inhibe ettiği gösterilmiştir.

Biz de bu çalışmamızda, kendi takip ettiğimiz $\mathrm{KBH}^{\prime} \mid$ hastalarda $D$ vitamini düzeyine etki eden faktörleri ve FGF-23 ile ilişkisini saptamayı amaçladık.

\section{GEREÇ ve YÖNTEM}

Çalışma hastane Etik Kurulu tarafından kabul edildi.

Ocak-Şubat 2015 tarihleri arasında hastanemiz nefroloji kliniğine başvuran, $\mathrm{KBH}^{\prime}$ lığı olan ve diyalize girmeyen 120 hasta çalışmaya alındı. Hastaların ortala-

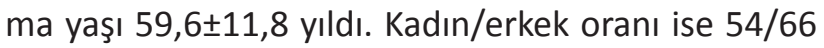
idi. Son 6 ay içinde enfeksiyon geçirenler, romatolojik hastalığı olanlar, karaciğer hastalığı olanlar, D vitamini kullananlar, C-reaktif protein (CRP)'si $5 \mathrm{ng} / \mathrm{ml}$ üs- tünde olanlar, 18 yaş altı olanlar, çalışmaya katılmayı reddedenler dahil edilmedi.

Tüm hastaların yazılı onamı alındıktan sonra yaş, cins, KBY etyolojisi, HT, DM varlığı, kullandıkları ilaçlar kaydedildi.

Rutin hemogram ve biyokimyasal değerlendirmeler için 8 saat açlık sonrası kan ve idrar örnekleri alındı. Hemoglobin $(\mathrm{Hb})$, hematokrit, beyaz küre, nötrofil, lenfosit ve trombosit sayıları, ortalama trombosit hacmi (OTH) , glukoz, kan üre nitrojen (BUN), kreatinin, kalsiyum, fosfor, paratroid hormon (PTH), albumin, CRP ve $25(\mathrm{OH})$ vitamin D düzeyleri kaydedildi. Hastaların tahmini glomerular filtrasyon hızları (eGFR) ise CKD-EPI formülü kullanılarak hesaplandı ${ }^{11}$.

FGF-23 ölçümü için gerekli serumu saklamak için venöz kan örnekleri 2000 g. de 10 dk. santrifüj edildikten sonra serumları $-80^{\circ} \mathrm{C}$ 'de saklandı. Serum FGF23 düzeyleri, FGF23 ELISA kit (catalogno. SEA746Hu; Cloud-CloneCorp., TX, USA) kullanılarak ölçüldü. Testin analitik duyarlıığı $6.7 \mathrm{pg} / \mathrm{mL}$ 'den azdı. İntra-assay ve inter-assay CV'ları sırasıyla $<\% 10$ ve $<\% 12$ idi.

Hastaların bel ve kalça çevreleri boy ve kiloları ölçüldü. Boy $(\mathrm{cm})$, hasta ayakkabılarını giymeden, normal pozisyonda sırtı duvara yasıı iken ölçüldü. Bel çevresi $(\mathrm{cm})$, göbek hizasından, kalça çevresi $(\mathrm{cm})$ ise kalçanın en geniş yerinden ölçüldü. Bel kalça oranı, bel çevresi $(\mathrm{cm})$ 'nin, kalça çevresine $(\mathrm{cm})$ bölünmesi ile hesaplandı. Bel boy oranı, bel çevresi $(\mathrm{cm})$ 'nin, boy $(\mathrm{cm})$ 'a bölünmesi ile hesaplandı. Vücut kitle indeksi (VKi) $\left(\mathrm{kg} / \mathrm{m}^{2}\right)$ ise kilonun $(\mathrm{kg})$, boyun $(\mathrm{m})$ metrekaresine bölünmesi ile hesaplandı.

\section{ISTATISTIK YÖNTEM}

Çalışmanın istatistiksel değerlendirmesi SPSS 16 (SPSS Inc., USA) bilgisayar programı kullanılarak yapıldı. Verilerin normal dağıııp dağılmadığı KolmogorovSmirnov Testi ile değerlendirildi. Gruplar arasındaki farklılıkların değerlendirilmesinde normal dağılmış sürekli veriler için Student t Testi, normal dağılmayanlar için ise Mann-Whitney $U$ Testi, kategorik veri- 
ler içinse $\mathrm{x}^{2}$ Testi kullanıldı. D vitamin düzeyi ve diğer faktörler arasında bir ilişki olup olmadığı ise Spearman korelasyon analizi ile test edildi. $\mathrm{D}$ vitamini düzeyine etki eden faktörleri saptamak için lineer regresyon analizi yapıldı. Sonuçlarda $p<0,05$ istatistiksel olarak anlamlı kabul edildi.

\section{BULGULAR}

Kırksekiz hastada (\%40) KBH'nın etiyolojisi HT, 37 hastada $(\% 30,8)$ DM, 11 hastada glomerulonefrit ve 24 hastada \%19,6) diğer nedenlerdi. Otuz sekiz $(\% 32,5)$ hasta KBH evre III iken, 48 hasta evre IV idi.

Hastaların $68(\% 56,7)$ 'inde D vitamini eksikliği, 47 $(\% 39,2)$ 'sinde D vitamini yetmezliği vardı. Yalnızca 5 $(\% 4,2)$ hastanın D vitamin düzeyi $30 \mathrm{pg} / \mathrm{ml}$ 'nin üstünde idi. Hastaların demografik ve laboratuar özellikleri Tablo 1'de gösterilmektedir.

Tablo 1. Hastaların demografik ve laboratuar özellikleri.

\begin{tabular}{ll}
\hline Yaş (yıl) & $59,6 \pm 11,8$ \\
Cins (E/K) & $54 / 66$ \\
DM (n,\%) & $35(\% 29,2)$ \\
Bel kalça & $0,96 \pm 0,08$ \\
Bel boy & $0,63 \pm 0,08$ \\
VKi $\left(\mathrm{kg} / \mathrm{m}^{2}\right)^{ \pm}$ & $28,6 \pm 5,8$ \\
$25(\mathrm{OH}) \mathrm{D}(\mathrm{ng} / \mathrm{mL})$ & $15,1 \pm 7,8$ \\
Kalsiyum $(\mathrm{mg} / \mathrm{dL})$ & $9,0 \pm 0,5$ \\
Fosfor $(\mathrm{mg} / \mathrm{dL})$ & $3,8 \pm 0,8$ \\
Albumin $(\mathrm{g} / \mathrm{dL})$ & $3,9 \pm 0,4$ \\
PTH $(\mathrm{pg} / \mathrm{mL})^{ \pm, * *}$ & $121,1(89-180)$ \\
FGF23 $(\mathrm{pg} / \mathrm{mL})^{\mu}$ & $112,4 \pm 50,4$ \\
Hg $(\mathrm{g} / \mathrm{dL})$ & $12,0 \pm 1,5$ \\
Nötrofil/lenfositoranı & $3,1 \pm 2,5$ \\
OTH (fL) & $8,4 \pm 1,6$ \\
CRP $(\mathrm{mg} / \mathrm{L})^{\alpha, * *}$ & $1,44(0,72-2,90)$ \\
Glukoz $(\mathrm{mg} / \mathrm{dL})$ & $107,8 \pm 35,5$ \\
eGFR (ml/dk/1.73 $\left.\mathrm{m}^{2}\right)^{€}$ & $27,1 \pm 9,6$ \\
Proteinüri $(\mathrm{g} / \mathrm{gün})^{* *}$ & $0,98(0,42-2,2)$ \\
\end{tabular}

*DM; diyabetes mellitus, ${ }^{\mp}$ VKi; vücut kitle indexi, ${ }^{ \pm}$PTH; parathormon, ${ }^{\mu}$ FGF-23; Fibroblast growth faktör 23, ${ }^{\mathrm{O}} \mathrm{OTH}$; ortalama trombosit hacmi, ${ }^{\alpha} C R P$ : C-reaktif protein, ${ }^{€}$ Egfr: glomerular filtrasyon hızı, **median (interquartile range)

Hastalar D vitamini düzeyi $15 \mathrm{pg} / \mathrm{ml}$ altında ve üstünde olanlar olmak üzere 2 gruba ayrıldı. $D$ vitamin düzeyi $<15 \mathrm{pg} / \mathrm{ml}$ olan 68 hasta grup l'i, eşit ve üstünde olan 56 hasta ise grup II'yi oluşturdu. Gruplar demografik ve laboratuvar özellikleri açısından karşılaştırıldı. Sonuçlar Tablo 2'de gösterilmektedir. Grup I hastalarda OTH ve PTH düzeyi daha yüksekti (sırasıyla $p<0,05, p<0,01)$.

Tablo 2. Hasta sonuçları ve gruplar arası istatistiksel karşılaştırma.

\begin{tabular}{|c|c|c|c|}
\hline & $\begin{array}{l}\text { D vitamin düzeyi } \\
<15 \mathrm{ng} / \mathrm{ml} \text { (n:68) }\end{array}$ & $\begin{array}{l}\text { D vitamin düzeyi } \\
\geq 15 \mathrm{ng} / \mathrm{ml} \text { (n:56) }\end{array}$ & $\stackrel{P}{\text { değeri }}$ \\
\hline Yaş (yıl) & $59,0 \pm 12,3$ & $60,4 \pm 11,3$ & 0,673 \\
\hline Cins (K/E) & $27 / 41$ & $27 / 25$ & 0,183 \\
\hline $\operatorname{DM}(n, \%)^{*}$ & $22(\% 32)$ & $13(\% 25)$ & 0,380 \\
\hline Bel kalça & $0,96 \pm 0,08$ & $0,96 \pm 0,09$ & 0,885 \\
\hline Bel boy & $0,64 \pm 0,09$ & $0,62 \pm 0,08$ & 0,176 \\
\hline VKi $\left(\mathrm{kg} / \mathrm{m}^{2}\right)^{ \pm}$ & $29,1 \pm 6,11$ & $27,9 \pm 5,46$ & 0,394 \\
\hline Kalsiyum (mg/dL) & $9,03 \pm 0,58$ & $9,0 \pm 0,42$ & 0,646 \\
\hline Fosfor (mg/dL) & $3,9 \pm 0,94$ & $3,6 \pm 0,61$ & 0,122 \\
\hline Albumin $(\mathrm{g} / \mathrm{dL})$ & $3,9 \pm 0,43$ & $4,0 \pm 0,35$ & 0,297 \\
\hline PTH $(\mathrm{pg} / \mathrm{mL})^{ \pm, * *}$ & $139,6(96,4-239,6)$ & $111(81,2-148,9)$ & 0,009 \\
\hline 25-OH-D (ng/mL) & $10,2 \pm 3,2$ & $21,5 \pm 7,4$ & 0,000 \\
\hline FGF23 $(\mathrm{pg} / \mathrm{mL})^{\mu}$ & $111,2 \pm 45,65$ & $113,9 \pm 56,51$ & 0,795 \\
\hline $\mathrm{Hg}(\mathrm{g} / \mathrm{dL})$ & $11,8 \pm 1,46$ & $12,3 \pm 1,66$ & 0,064 \\
\hline Nötrofil/lenfositoranı & $3,4 \pm 3,16$ & $2,6 \pm 1,04$ & 0,246 \\
\hline OTH $(\mathrm{fL})^{£}$ & $8,6 \pm 1,64$ & $8,0 \pm 1,48$ & 0,040 \\
\hline $\operatorname{CRP}(\mathrm{mg} / \mathrm{L})^{\alpha,{ }^{* *}}$ & $1,47(0,59-3,44)$ & $1,32(0,87-2,78)$ & 0,935 \\
\hline Glukoz (mg/dL) & $107,5 \pm 32,5$ & $108,3 \pm 39,4$ & 0,857 \\
\hline eGFR $\left(\mathrm{ml} / \mathrm{dk} / 1.73 \mathrm{~m}^{2}\right)^{€}$ & $27,01 \pm 9,9$ & $27,2 \pm 9,22$ & 0,699 \\
\hline Proteinüri (g/gün) ${ }^{* *}$ & $1,11(0,46-3,5)$ & $0,96(0,39-1,85)$ & 0,120 \\
\hline
\end{tabular}

${ }^{*} D M$; diyabetes mellitus, ${ }^{\mp} V K i ;$ vücut kitle indexi, ${ }^{ \pm} P T H$; parathormon, $\mu$ FGF-23; Fibroblast growth faktör 23, £OTH; ortalama

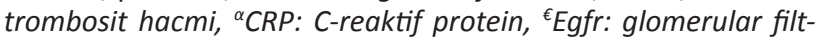
rasyon hızı, ${ }^{* *}$ median (interquartile range)

Hastalar VKi'lerine göre ayrıldıklarında VKi'i 18 altında olan hasta yoktu. VKi 18-25 arasında 36 hasta, 25-30 arası 39, 30-35 arası 32, 35 üstünde 13 hasta mevcuttu. Hastalar VKI'lerine göre karşılaştırıldığında D vitamini düzeyleri, VKI artıkça azalmasına rağmen, gruplar arasında istatistiksel olarak anlamlı fark bulunamadı $(\mathrm{p}: 0,71)$

DM olanlar ve olmayanlar karşılaştırıldığında ise DM olanlarda D vitamini düzeyi; $12,9 \pm 6,6 \mathrm{pg} / \mathrm{ml}$ iken, DM olmayanlarda bu düzey $16,0 \pm 8,1$ idi. Aradaki fark istatistiksel olarak anlamlıydı $(p<0,05)$.

Spearman korelasyon analizi sonucunda D vitamini, fosfor ( $r s=-0,30, p<0,001)$, PTH $(r s=-0,34, p<0,000)$, proteinüri $(r s=-0,22, p<0,05), D M$ varlığı $(r s=-0,19$, $\mathrm{p}<0,05)$ ile negatif korele iken, $\mathrm{Hb}(\mathrm{rs}=0,27, \mathrm{p}<0,001)$ ile pozitif korele idi. D vitamini ile FGF-23 ( $r s=-0,122$, $p=0,183)$, eGFR ( $r s=0,135, p=0,41)$ ve CRP ( $r s=0,004$, $\mathrm{P}=0,965$ ) arasında ise korelasyon saptanamadı FGF- 
23 ile D vitamini arasındaki ilişki Figür 1'de, CRP ile ilişkisi ise Figür 2'de eGFR ile olan ilişkisi ise Figür 3'te gösterilmektedir.

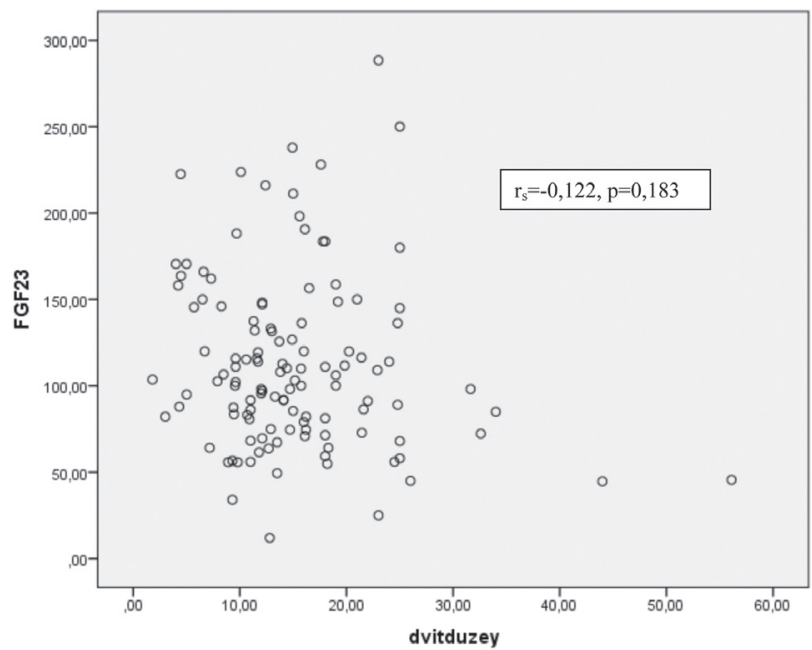

Figür 1. D vitamini ve FGF-23 düzeyi arasındaki korelasyon ilişkisi.

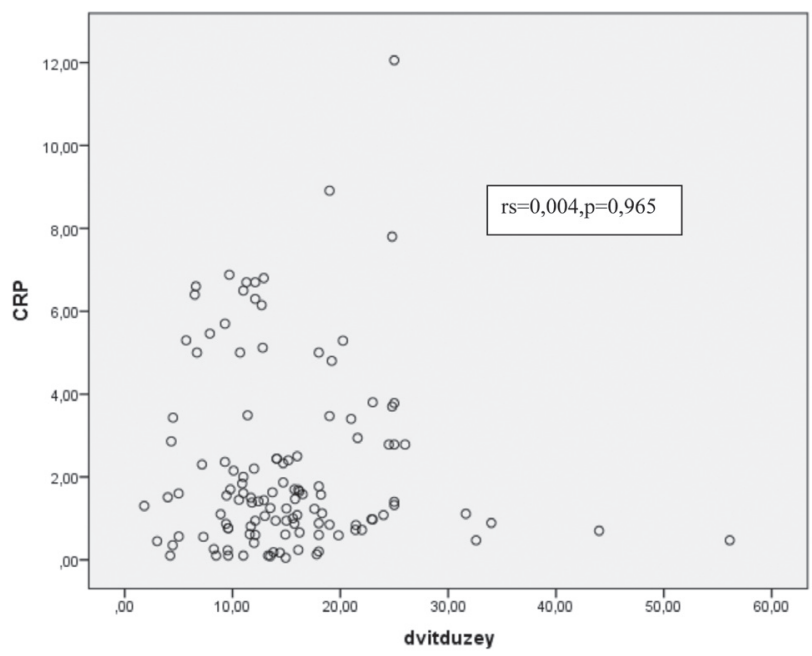

Figür 2. D vitamini ve CRP düzeyi arasındaki korelasyon ilişkisi.

D vitamini düzeyi üzerine etkili faktörleri saptamak için yaş, cins, VKi, kalsiyum, fosfor, PTH, FGF23, Hb, OTH, nötrofil/lenfosit oranı, proteinüri, CRP, eGFR ile oluşturulan modelle yapılan multivariate lineer regresyon analizinde (model $r$ : 0,555, adjusted $\mathrm{r} 2$ : 0,22) ise yalnızca PTH (Beta $=-0,24, p<0,01$ ), eGFR (Beta=$0,215, p<0,05) D$ vitamini üzerine negatif etkili bulundu.

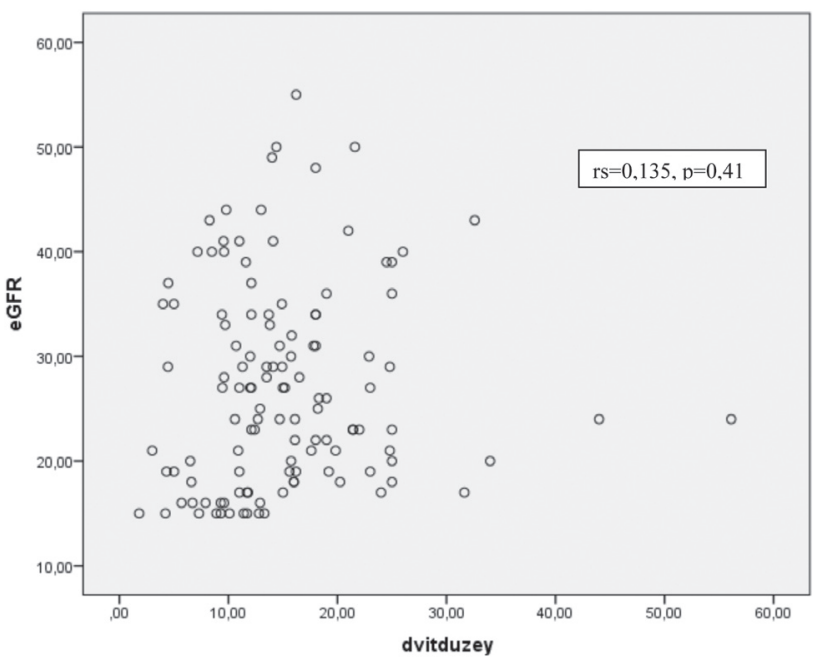

Figür 3. D vitamini ve eGFR arasındaki korelasyon ilişkisi.

\section{TARTIŞMA}

Çalışmamızda, D vitamini eksikliği-yetmezliğini \%95,8 gibi yüksek bir oranda saptadık. D vitamini, DM olan hastalarda olmayanlara göre istatistiksel olarak önemli derecede düşüktü. D vitamini düzeyi, fosfor, proteinüri ve DM varlığı ile negatif korele idi. D vitamini ile FGF-23, eGFR ve CRP arasında korelasyon yoktu. Multivariate lineer regresyon analizi yapıldığında ise D vitamini üzerine etkili olan faktörler olarak PTH ve eGFR bulundu.

D vitamininin obez bireylerde daha düşük olduğu gösterilmiştir. Bunun D vitaminin yağ dokuda birikmesi, obez bireylerin daha az dışarı çıkması ile güneş ışınlarına daha az maruz kalmasına bağlı olduğu düşünülmektedir. Echida ve ark.'nın ${ }^{12}$ yaptığı çalışmada, $D$ vitamini düzeyi yaş ve VKi ile ilişkili saptanmıştır. Biz de çalışmamızda, VKi artıkça D vitamini düzeyi azalmış bulmamıza rağmen, aradaki fark istatistiksel olarak anlamlı değildi. Yine visseral obesite belirteçleri olarak kabul edilen belkalça ve belboy oranı ile $D$ vitamini düzeyi arasında herhangi bir ilişki saptayamadık. VKi'nin yağ oranı göstermede güçlü bir belirleyici olmadığı bilinmektedir. Yaş ve D vitamini arasında ise herhangi bir ilişki saptayamadık. Bu hasta grubumuzun genç olmasından ve fiziksel olarak daha aktif olmasından kaynaklanıyor olabilir.

D vitamini eksikliği/yetmezliğinin inflamasyon belir- 
teci olan lökosit telomer uzunluğunda kısalma, artmış CRP ve IL-6 seviyeleri ile ilişkili olduğu gösterilmiştir ${ }^{13}$. Biz de daha önce böbrek nakilli hastalarda D vitamini düzeyinin, bir inflamasyon belirteci olan OTH ile ilişkili olduğunu göstermiştik ${ }^{14}$. Bu çalışmada ise, OTH'ı, vitamin D eksikliği olan hastalarda yüksek bulmamıza rağmen, regresyon analizinde bu ilişki devam etmedi. CRP ile D vitamini arasında da bir ilişki saptayamadık. $\mathrm{Hb}$ düzeyinin inflamasyondan etkilendiği bilinmektedir. Biz de Üçüncü Sağlık ve Beslenme Değerlendirme (NHANES III) çalışmasında bulunana benzer şekilde, $\mathrm{Hb}$ düzeyini, $\mathrm{D}$ vitamini düzeyi ile pozitif korele bulduk $^{15}$. Bu da D vitaminin inflamasyon ile ilişkili olduğunu indirekt bir göstergesi olabilir.

D vitamininin pankreas beta hücreleri üzerindeki reseptörleri aracılığı ile insülin sekresyonunu arttırdığı bilinmektedir $^{16-18}$. Daha önce yapılan çalışmalarda da $D M$ ve insülin direnci $D$ vitamini düzeyi ilişkili bulunmuştur ${ }^{19}$. DM varlığı ile D vitamini düzeyi korele olmasına rağmen, multivariatelineer regresyon analizinde bu ilişki gösterilemedi. Bunun nedeni hastaların yarısından azının DM olmasından ve yine hastaların genç olmasından kaynaklanabilir. Neden-sonuç ilişkisinin açıklanması için D vitamininreplasmanı sonrası DM ile ilişkisini gösteren kontrollü bir çalışmaya ihtiyaç vardır.

Sato ve ark. ${ }^{20}$ nefrotik sendromlu hastalarda D vitamini eksikliği ve proteinüri ilişkisini göstermiştir. Daha sonra yapılan çalışmalarda da diyabet varlığı, böbrek fonksiyonlarının düzeyi ve proteinürinin derecesinde bağımsız olarak proteinüri ve $D$ vitamini eksikliği arasındaki ilişki gösterilmiştir ${ }^{3,4}$. Çalışmamızda proteinüri ve $D$ vitamini korele saptanmasına rağmen, $D$ vitamini düzeyini etkileyebilen diğer faktörlere göre düzeltme yapıldığında bu ilişki kaybolmuştur.

Nakano ve ark.'nın ${ }^{21}$ yaptığı çalışmada da, FGF-23, 1,25-OH-D vitamini düzeyi ile ilişkili bulunmuştu. Çalışmamızda $D$ vitamini düzeyinin rutinde kullanılan ve daha stabil bir molekül olan 25-OH-D düzeyine bakarak değerlendirdik. FGF 23 ile 25-OH-D arasında ise herhangi bir ilişki saptayamadık. D vitamini düzeyini, klasik kemik mineral metabolizması döngüsünde rol alan PTH ve fosfor düzeyi ile negatif ilişkili bulduk. Normal bireylerde D vitamini düzeyi arttıkça, bağırsaklardan fosfor emilimi artar ve aralarında pozitif korele bir ilişki saptanır. KBH'lı hastalarda ise GFR azaldıkça fosfor klirensi azalır ve kanda fosfor düzeyi artarken diğer yandan D vitamini üretimi azalır. ÇaIışmamızda ise, GFR ile D vitamini arasında negatifkorelasyon saptadık. Korelasyon katsayısının düşük olması bu ilişkinin hasta sayımızın azlığı ile ilgili olan bir sonuç olduğunu düşündürmektedir.

Son yıllarda, D vitaminin klasik mineral metabolizması dışında pleotropik rolü ve özelliklede prediyaliz KBH'lihastalarda bunun klinik sonuçları daha iyi anlaşılmıştır. Bu nedenle de bu hasta grubunda D vitamini düzeyine etki eden faktörleri bilmek ve hastanın tedavisinde bunları göz önüne almak büyük önem taşımaktadır. Bu konuda ve D vitamini replasmanının klinik sonuçları konusunda dahi ileri çalışmalara gereksinim vardır.

Çalışmamızın başlıca limitasyonu hasta sayısının azlığıdır. Obesite değerlendirilmesinde vücut yağ oranını en güvenilir testler olan magnetik rezonans ve tomografinin kullanılmaması da bir diğer limitasyonudur. Bu çalışmada $\mathrm{KBH}^{\prime}$ lı hastalarda D vitamini ile ilişkili faktörlerin özellikle de FGF-23 ile D vitamini arasındaki ilişkinin araştırılması amaçlanmıştır. D vitamini ve FGF-23 arasında herhangi bir ilişki bulunamamıştır.

\section{KAYNAKLAR}

1. Holick MF. Vitamin D deficiency. Am N Engl J Med. 2007;357:266-81.

https://doi.org/10.1056/NEJMra070553

2. Heaney RP. Vitamin D in health and disease. Am Clin J Am SocNephrol. 2008;3:1535-41. https://doi.org/10.2215/CJN.01160308

3. Cuppari L, Carvalho AB,Draibe SA. Vitamin D status of chronic kidney disease patients living in a sunny country. J Ren Nutr. 2008;18:408-14.

https://doi.org/10.1053/j.jrn.2008.05.004

4. Mehrotra R, Kermah D, Budoff M, et al. HypovitaminosisD in chronic kidney disease. Clin J Am Soc Nephrol. 2008;3:114451.

https://doi.org/10.2215/CJN.05781207

5. Gonzalez EA, Sachdeva A, Oliver DA, Martin K.J. Vitamin D insufficiency and deficiency in chronic kidney disease. A single center observational study. Am J Nephrol. 2004;24:503-10. 
https://doi.org/10.1159/000081023

6. Eknoyan G, Levin A, Levin N. K/DOQI clinical practice guidelines for bone metabolismand disease in chronic kidney disease. Am J Kidney Dis. 2003;42:S1-S201. https://doi.org/10.1016/S0272-6386(03)00905-3

7. Ravani P, Malberti F, Tripepi G, et al. Vitamin D levels and patient outcome in chronic kidney disease. Kidney Int 2009;75:88-95. https://doi.org/10.1038/ki.2008.501

8. Ishimura E, Nishizawa $Y$, Inaba $M$, et al. Serum levels of1,25dihydroxyvitamin D, 24,25-dihydroxyvitamin D, and 25hydroxyvitamin $D$ in nondialyzed patients with chronic renal failure. Kidney Int. 1999;55:1019-27. https://doi.org/10.1046/j.1523-1755.1999.0550031019.x

9. Danzige J. The bone-renal axis in early chronic kidney disease: an emerging paradigm. Nephrol Dial Transplant. 2008;23:2733-7. https://doi.org/10.1093/ndt/gfn260

10. Seiler S, Heine GH, Fliser D. Clinical relevance of FGF-23 in chronic Kidney disease. Kidney Int. 2009;76(Suppl14);534-42. https://doi.org/10.1038/ki.2009.405

11. Levey AS, Stevens LA, Schmid $\mathrm{CH}$ et al. A new equation to estimate glomerular filtration rate. Ann Intern Med. 2009;150(9):604-12. https://doi.org/10.7326/0003-4819-150-9-20090505000006

12. Echida Y, Mochizuki T, Uchida K, Tsuchiya K, Nitta K. Risk factors for vitamin $\mathrm{D}$ deficiency in patients with chronic kidney disease.Intern Med. 2012;51(8):845-50. https://doi.org/10.2169/internalmedicine.51.6897

13. Querfeld U. Vitamin D and inflammation.Pediatr Nephrol. 2013 Apr;28(4):605-10. https://doi.org/10.1007/s00467-012-2377-4
14. Sasak G, Oral A, Bascı S. The relationship between vitamin $D$ deficiency and increased mean platelet volume in renal transplant recipients. Med Med J. 2017;32(2):106-10.

15. KendrickJ, Targher G, Smits G, Chonchol M. 25-Hydroxyvitamin $D$ deficiency and inflammation and their association with hemoglobin levels in chronic kidney disease. Am J Nephrol. 2009;30:64-72. https://doi.org/10.1159/000202632

16. Chiu CK, Chu A, Go VLW, Saad MF. Hypovitaminosis D isassociated with insulin resistance and cell dysfunction. Am J Clin Nutr. 2004;79:820-5. https://doi.org/10.1093/ajcn/79.5.820

17. Palomer X, Gonz_alez-Clemente JM, Blanco-Vaca F, Mauricio D. Role of vitamin $D$ in the pathogenesis of type 2 diabetes mellitus. Diab Obes Metab. 2008;10:185-97.

18. Ford ES, Ajani UA, McGuire LC, Liu S. Concentrations of serum vitamin $\mathrm{D}$ and the metabolic syndrome among U.S. adults. Diabetes Care. 2005;28:1228-30.

https://doi.org/10.2337/diacare.28.5.1228

19. Figuiredo-Dias V, Cuppari L, Garcia-Lopes MG, De Carvalho $A B$, Draibe SA, Kamimura MA. Risk factors for hypovitaminosis $D$ in nondialyzed chronic kidney disease patients. J Ren Nutr. 2012; 22(1):4-11. https://doi.org/10.1053/j.jrn.2011.02.001

20. Sato KA, Gray RW, Lemann J. Urinary excretion of 25hydroxyvitamin $D$ in health and the nephrotic syndrome. J Lab Clin Med. 1982;99:325-30.

21. Nakano C, Hamano T, Fujii N, et al. Combined use of vitamin D status and FGF23 for risk stratification of renal outcome. Clin J Am Soc Nephrol. 2012;7(5):810-9. https://doi.org/10.2215/CJN.08680811 